OPEN ACCESS

Edited by:

Chan-Wang Jerry Lio,

The Ohio State University,

United States

Reviewed by:

Jenny Mjösberg,

Karolinska Institutet (KI), Sweden

Elia Tait Wojno,

Cornell University, United States

*Correspondence:

Han-Yu Shih

han-yu.shih@nih.gov

Specialty section: This article was submitted to

B Cell Biology,

a section of the journal

Frontiers in Immunology

Received: 19 January 2021 Accepted: 09 March 2021

Published: 25 March 2021

Citation:

Fernando N, Sciumè G, O'Shea JJ and Shih H-Y (2021) Multi-Dimensional

Gene Regulation in Innate and

Adaptive Lymphocytes: A View

From Regulomes.

Front. Immunol. 12:655590.

doi: 10.3389/fimmu.2021.655590

\section{Multi-Dimensional Gene Regulation in Innate and Adaptive Lymphocytes: A View From Regulomes}

\author{
Nilisha Fernando ${ }^{1}$, Giuseppe Sciumè ${ }^{2}$, John J. O'Shea ${ }^{3}$ and Han-Yu Shih ${ }^{1,4^{*}}$ \\ ${ }_{1}^{1}$ Neuro-Immune Regulome Unit, National Eye Institute, National Institutes of Health, Bethesda, MD, United States, \\ 2 Laboratory Affiliated to Istituto Pasteur Italia - Fondazione Cenci-Bolognetti, Department of Molecular Medicine, Sapienza \\ University of Rome, Rome, Italy, ${ }^{3}$ Lymphocyte Cell Biology Section, Molecular Immunology and Inflammation Branch, \\ National Institute of Arthritis, Musculoskeletal and Skin Diseases, National Institutes of Health, Bethesda, MD, United States, \\ ${ }^{4}$ National Institute of Neurological Disorders and Stroke, National Institutes of Health, Bethesda, MD, United States
}

The precise control of cytokine production by innate lymphoid cells (ILCs) and their T cell adaptive system counterparts is critical to mounting a proper host defense immune response without inducing collateral damage and autoimmunity. Unlike $T$ cells that differentiate into functionally divergent subsets upon antigen recognition, ILCs are developmentally programmed to rapidly respond to environmental signals in a polarized manner, without the need of T cell receptor (TCR) signaling. The specification of cytokine production relies on dynamic regulation of cis-regulatory elements that involve multidimensional epigenetic mechanisms, including DNA methylation, transcription factor binding, histone modification and DNA-DNA interactions that form chromatin loops. How these different layers of gene regulation coordinate with each other to fine tune cytokine production, and whether ILCs and their T cell analogs utilize the same regulatory strategy, remain largely unknown. Herein, we review the molecular mechanisms that underlie cell identity and functionality of helper T cells and ILCs, focusing on networks of transcription factors and cis-regulatory elements. We discuss how higher-order chromatin architecture orchestrates these components to construct lineage- and state-specific regulomes that support ordered immunoregulation.

Keywords: signal-regulated transcription factors, lineage-determining transcription factors, de novo enhancers, poised enhancers, ATAC-seq and chromatin accessibility, innate lymphoid cell (ILC), histone modifications

\footnotetext{
Abbreviations: 3C, chromatin conformation capture; ATAC-seq, Assay for Transposase-Accessible Chromatin using sequencing; ChIP, chromatin immunoprecipitation; circRNA, circular RNA; CTCF, CCCTC-binding factor; CTL, cytotoxic T lymphocyte; EOMES, eomesodermin; GATA-3, GATA-binding protein 3; H3K27Ac, histone 3 lysine 27 acetylation; IFN- $\gamma$, interferon gamma; IL, interleukin; ILC, innate lymphoid cell; LDTF, Lineage-Determining Transcription Factor; lncRNA, long non-coding RNA; LTi, Lymphoid tissue inducer cell; miRNA, microRNA; NCR, natural cytotoxicity

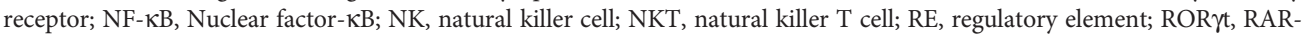
related orphan receptor gamma; SE, super-enhancer; SRTF, Signal-Regulated Transcription Factor; STAT, signal transducer and activator of transcription; TAD, topologically associating domains; TCR, T cell receptor; TF, transcription factor; Th cell, helper $\mathrm{T}$ cell.
} 


\section{REGULOMES DEFINE DIVERGENT LYMPHOCYTE TRANSCRIPTIONAL PROGRAMS}

Each nucleus contains six billion nucleotides compacted into nucleosomes as basic units of chromatin that are orderly compacted and compartmentalized for precise gene regulation $(1,2)$. Residing among $98 \%$ of non-coding mammalian genomes are nearly three million regulatory elements (REs) that control the expression of approximately 20,000 genes in a cell-specific manner upon developmental and environmental cues (3). In lymphocytes, large networks of REs and transcription factors (TFs) orchestrate transcriptional and phenotypic diversity (4-6). The majority of REs are enhancers that remotely modulate transcription from a distance. However, the mechanisms of how intrinsic and extrinsic cues control enhancer activities to coordinate cell type- and state-specific gene expression profiles are yet to be understood.

Innate lymphoid cells (ILCs) play critical roles in tissue homeostasis, barrier integrity and primary host defense and mirror the functionalities of their effector counterparts in the adaptive immune compartment, $\mathrm{CD} 4^{+}$helper $\mathrm{T}(\mathrm{Th})$ and $\mathrm{CD} 8^{+}$ cytotoxic T lymphocytes (CTL) (7-10). The similarities between innate and adaptive lymphocyte programming have dramatically accelerated our understanding of ILC regulation using the knowledge accumulated from studies of $\mathrm{T}$ cells (11-14). Other innate-like $\mathrm{T}$ cells, such as NKT cells, that mirror their functional $\mathrm{T}$ cell analogs also reveal similar lineage programming during development at both transcriptomic and epigenomic levels, which is beyond the scope of this review $(15,16)$. Here, we will focus on how cell identity and function are epigenetically imprinted during ILC maturation and how environmental signals activate or maintain ILC regulomes that define their transcriptomes.

\section{REGULOMES OF ILCS AND THEIR T CELL DOPPELGÄNGERS}

Immune responses mounted against pathogens can be categorized into three main programs (17). Type 1 immunity is manifested by IFN- $\gamma$ production in natural killer (NK) cells, CTLs, type 1 ILC (ILC1) and type 1 Th cells (Th1) to control intracellular pathogens. Type 2 immunity is characterized by interleukin (IL)-4, IL-5, IL-9 and IL-13 production from ILC2 and Th2 cells in defense against extracellular helminths. Finally, type 3 immunity is defined by the production of IL-17 and IL-22 in ILC3 and Th17/22 cells to constrain extracellular fungi and bacteria $(10,18-20)$.

These distinct, but sometimes overlapping, programs are specified by key lineage-determining transcription factors (LDTFs) that shape regulomes by acting as master regulators to control lymphocyte development and differentiation (2123). EOMES, a T-box family TF, oversees initial NK cell development and CTL differentiation into effector and memory stages (24-31). T-bet, another T-box family TF encoded by $T b \times 21$, also directs the type 1 immune response by coordinating with EOMES for CTL memory establishment and maintenance and enforcing NK cell maturation. T-bet expression is exclusively essential for both lineage specification and function in ILC1 and Th1 cells, as these lymphocytes do not express EOMES $(32,33)$. High level expression of GATAbinding protein 3 (GATA-3, encoded by the Gata3 gene) plays a key role in ILC2 and Th2 cell differentiation and cytokine production (34-36). Finally, type 3 immunity is governed by RAR-related orphan receptor gamma, ROR $\gamma t$ (encoded by the Rorc gene), which controls ILC3 and Th17 lineage specification and cytokine secretion $(37,38)$. These LDTFs epigenetically activate and stabilize function-related gene expression and, at the same time, inhibit transcription of genes that contribute to alternative cell fates $(8,39)$.

REs are typically characterized as conserved non-coding DNA sequences that become nucleosome-depleted to permit TF binding. For many years, identification and characterization of functional REs required extraordinary but often imprecise efforts. Use of computational prediction of REs through sequence conservation provided candidates that required further validation by assessment of chromatin accessibility by a DNase hypersensitivity assay or chromatin immunoprecipitation (ChIP) assays using antibodies directed at acetylated histone marks $(40,41)$. Similarly, the crosstalk between REs, such as enhancer-promoter interactions, has been measured by chromatin conformation capture (3C) or 3C-based assays (42). However, the development of massively parallel genomic DNA sequencing incorporating with conventional assays (e.g. DNaseseq, ChIP-seq, Hi-C) ushered in a new era of epigenomic research (43-46). These methods have been applied to map the regulomes of a wide range of immune cell populations, including T cells, B cells and macrophages $(6,47-52)$. $\mathrm{CD} 4^{+}$naïve $\mathrm{T}$ cells, for instance, establish lineage-specific regulomes during terminal differentiation that underlie Th cell identity and effector function (53-58). The improvement of relevant molecular biology techniques, including single cell RNA-seq (59), assay of transposase-accessible chromatin using sequencing (ATACseq) (60), ultra-low-input native ChIP-seq (61) and indexing first ChIP (iChIP) (62), further allows for the systematic interrogation of global transcriptomes and regulomes in low cell and rarer populations, including ILCs. Similar to their Th analogs, ILC subsets revealed cell-type restricted regulomes that define their lineage and effector competence $(38,63-66)$. These pre-programmed epigenomic configurations prime the REs at both TF and cytokine loci to maintain cell identity and enable rapid innate immune responses.

In contrast to Th cells that reshape naïve $\mathrm{T}$-cell chromatin landscapes into divergent $\mathrm{Th}$ regulomes in response to combinational TCR and cytokine stimulation (54-56, 67), ILCs gradually construct lineage-specific, function-related regulomes during development prior to activation $(38,64)$. Un-supervised hierarchical clustering of murine immune cell regulomes clearly segregates ILCs from T lymphocytes (64). Similar results were obtained in humans when comparing type 1 and type 3 innate and adaptive lymphocytes from pediatric tonsils (63), consistent with the finding that regulomes are highly conserved across species (68). 
Interestingly, while encountering challenges such as infection, innate and adaptive lymphocyte analogs converge their regulomes to execute overlapped effector activities to synergize host defense $(64,69)$. For example, upon Nippostrongylus brasiliensis infection in mice, naïve $\mathrm{T}$ cell regulomes are transformed into Th2 regulomes that resemble ILC2 regulomes, while ILC2 regulomes were minimally altered (64). Similarly, in mouse cytomegalovirus infection, effector NK cells and $\mathrm{CD}^{+} \mathrm{T}$ cells exhibit higher epigenomic commonality compared to naïve $\mathrm{NK}$ and $\mathrm{CD}^{+}$cells (69). Also, global DNA methylation patterns of adaptive NK cells in human cytomegalovirus were highly similar to the profile observed in $\mathrm{CD}^{+} \mathrm{T}$ cells (70). The convergence of ILC and T cell regulomes indicates a conservation of intrinsic regulatory networks in innate and adaptive compartments along with the impact of extrinsic signals.

During the course of mouse cytomegalovirus infection, NK cells acquire an adaptive-like phenotype that provides memory responses similarly to those of $\mathrm{T}$ cells (71). This process involves acquisition of both stable and transient epigenetic changes, although the majority of accessible sites return to the naïve state (Figure 1) (69). Notably, naïve and memory $\mathrm{CD}^{+} \mathrm{T}$ cell regulomes are clustered in proximity in the un-supervised hierarchical clustering analysis, suggesting a naïve-like chromatin landscape in memory $\mathrm{T}$ cells (64). Upon NK cell activation, REs associated with Socs3, Cish, Pdcd1, Dnmt3a, and $I 110$ gene loci acquire stable DNA-accessibility, while REs near Tbx21, Klrg1, Ifng, and Zbtb32 are associated with transient modifications (69). Interferon-stimulated response element-like sequences were enriched in peaks remaining accessible over time, while motifs for TCF-LEF and NF- $\kappa B$ family members were enriched in regions becoming less accessible and undergoing epigenetic poising (69). Nevertheless, in contrast to naïve and infected ILC regulomes that are clustered in close proximity, terminally differentiated effector Th cells are clustered distally from naïve $\mathrm{T}$ cells (64). A recent study indicates that environmental challenges like microbes in gut heavily contribute to the continuous effector Th cell distribution of both transcriptomes and epigenomes (73). This finding suggests that adaptive T cells bear a more plastic character as compared to ILCs.

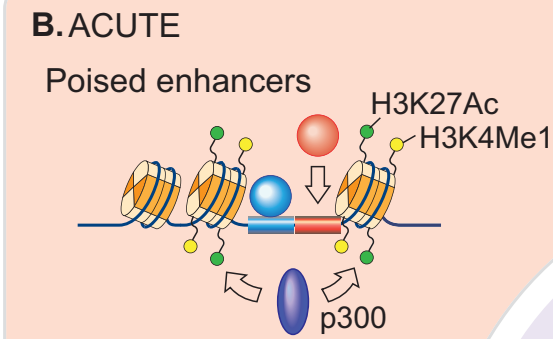

LDTF-targeted accessible REs recruit SRTFs and other factors

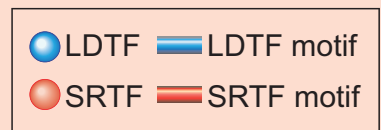

\section{De novo enhancers}

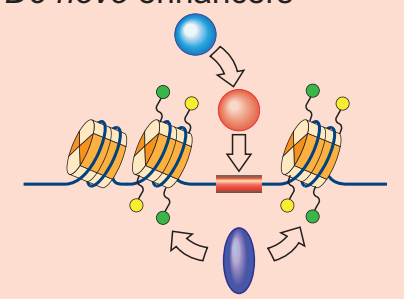

SRTFs open inaccessible REs to recruit LDTFs and other factors
A. DYNAMIC REGULOMES DURING INFECTION

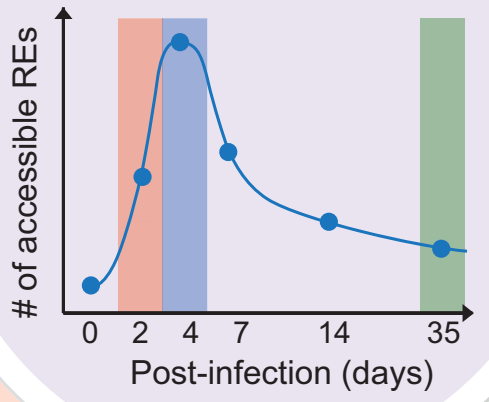

Transient

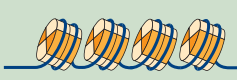

Opened REs return to naïve-state

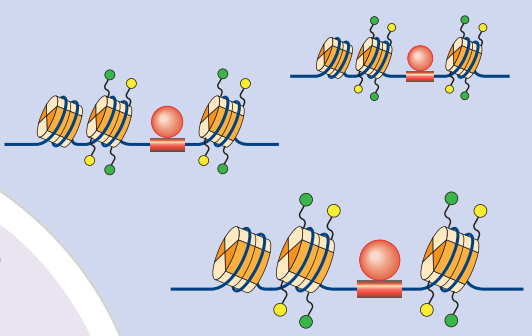

Increased number of accessible REs

\section{MEMORY}
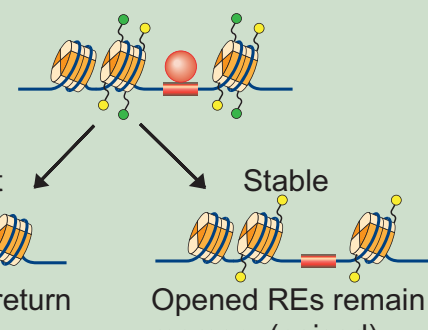
memory (poised)

FIGURE 1 | Dynamics of NK cell regulomes during infection. (A) Dynamic regulomes during infection. Innate immune response occurs along with changes in gene expression as well as chromatin accessibility. (B) High-magnitude gene upregulation during NK cell activation relies on recruitment of signal-regulated transcription factors (SRTFs) to poised enhancers that are developmentally acquired in a lineage-determining transcription factors (LDTFs) manner for chromatin remodeling (top) (72). High-magnitude gene induction also forms de novo enhancers through a process involving sequence-specific binding of SRTFs to inaccessible chromatin regions, followed by LDTF recruitment and enhancer activation (bottom) (72). (C) Formation of new accessible sites rapidly occurs in vivo upon mouse cytomegalovirus or Toxoplasma gondii infection until a peak of the response is reached (69). (D) At the end of viral infection, majority of these rapidly opened chromatins return to resting state, while part of them undergo stable epigenetic poising that maintains NK cell adaptive-like or memory phenotype (69, 70). 


\section{TRANSCRIPTION FACTORS SHAPE LYMPHOCYTE SUBSET REGULOMES}

During development, inaccessible REs are recognized by pioneer TFs in a sequence-specific manner. This is followed by chromatin remodeling, which propagates heritable epigenetic information that instructs cell identity (74). LDTFs are often considered as pioneer TFs, specifying lymphocyte lineage fates by targeting selective REs. In macrophages and B cells, PU.1 is an LDTF that occupies the majority of the active enhancers and is required for nucleosome remodeling and histone 3 lysine 4 methylation of these REs (75). The enrichment of T-bet, GATA-3 and ROR $\gamma$ t motifs in type 1, 2 and 3 ILC-specific accessible chromatins, respectively, leads to the question whether LDTFs can directly open the chromatin or cooperate with other factors to shape ILC regulomes during development $(23,63,64)$. More recently, the integration of transcriptomic analysis and TF motif analysis, obtained by chromatin accessibility data, has been applied to predict the role for almost one hundred TFs in the regulation of ILC identity, in mice. These data reveal the ability of TFs to both activate or repress gene expression corresponding to alternative ILC fates (23).

Several LDTFs involved in T lymphocyte development also control ILC development in mice, likely controlling this process by shaping their regulomes. These LDTFs include TCF-1 (encoded by the Tcf7 gene) (76-78), TOX (79-81), Bcl11b (8284), Runx $(85,86)$ and GATA-3 (87-91). During early T cell development in the thymus, TCF1 and Bcl11b sequentially switch $\mathrm{T}$ cell regulomes to a fate-committed configuration that possess lineage-specific accessible chromatin and nuclear organization $(92,93)$. Notably, in different lineages the same LDTFs can bind divergent sites in a context-dependent manner $(85,91,94)$. Bcl11b, for example, targets different genomic locations in T cell progenitors and ILC 2 s, mediating lineagespecific gene regulation (94). Therefore, in depth experimental evaluation is required to map out complete ILC lineage- and state-specific transcriptional networks.

By contrast, some LDTFs bifurcate T and ILC development and contribute to initial steps in ILC regulome formation. NFIL3, for example, is essential for multiple stages of ILC lineage commitment and differentiation, but is dispensable in $\mathrm{T}$ cell development (95-98). High expression of NFIL3 in common ILC progenitors activates the NFIL3-TOX-TCF-1 cascade to permit differentiation of NK and ILC lineages from T cells and endorses NK and ILC lineage commitment $(81,96)$. NFIL 3 is also required for the expression of ID2 $(95,99,100)$; the latter is a key repressor that suppresses $\mathrm{B}$ and $\mathrm{T}$ cell fates to ensure ILC and NK cell specification (101-103). Depletion of ID2 enforces NK cells to acquire naïve $\mathrm{T}$ lymphocyte transcriptomic and epigenomic programs (102). Transient expression of PLZF (encoded at Zbtb16), another key LDTF associated with NKT cell development, plays an essential role in the commitment of ILC1, ILC2 and NCR ${ }^{+}$ILC3 subsets and the exclusion of NK cell and LTi fates during early ILC development $(104,105)$. However, the potential of ILC precursors has been recently redefined by the generation of $I d 2^{R F P} Z b t b 16^{G F P c r e} B c l 11 b^{\text {tdTomato }}$ mice, showing that $\mathrm{Id} 2^{+} \mathrm{Zbtb} 16^{+}$ILC precursors are able to give rise to NK cells, while Zbtb16 and Bcl11b control the late fates of ILC3 and ILC2 precursors (106).

In addition to LDTFs, signal-regulated transcription factors (SRTFs) activated by external signals can also lead to regulome transformation. In effector Th cells, activation-induced SRTFs (AP-1, IRF4 and BACH2) have a higher impact on the segregation of T cell populations than LDTFs do (T-bet, EOMES, ROR $\gamma$, and ROR $\alpha$ ) (73). Interestingly, the signaling pathways that dominate lymphocyte development and activation are in common at a significant level (39, 107). Polarization of distinct Th subsets requires activation of TCRdependent SRTFs, including NF- $\mathrm{\kappa B}, \mathrm{AP}-1$ and NFAT, as well as cytokine-mediated SRTFs like STATs and SMADs (108). Activation of STATs is essential for promoting differentiation of the Th lineages, as well as activation of ILCs and NK cells (109-112). The LDTFs Tbet and GATA-3 occupy lineage-specific REs in Th1 and Th2 cells, respectively; however, the absence of STAT4 and STAT6, which respectively shape Th1 and Th2 active enhancer landscapes, cannot be overcome by forced expression of LDTFs $(56,113)$. Additionally, polarization of Th17 cells relies on STAT3 and SMAD2/3 signaling pathways, which also promote activation of ILC3 and transdifferentiation of ILC1 or ILC2 lymphocytes to an ILC3-like phenotype $(109,114,115)$. Other agonists, including cytokines and alarmins like IL-25, IL-33 and IL-18, along with leukotrienes, prostaglandin 2, and the neuropeptide neuromedin $\mathrm{U}$ can lead to NF- $\mathrm{BB}, \mathrm{AP}-1$ and NFAT activation (116-121).

ILC regulomes are hard-wired to prime cytokines and other key effector genes for rapid responses. The paradigmatic view is that SRTFs facilitate rapid gene induction by activating enhancers primed during ILC development. For example, the SRTF STAT5 represents a central node in ILC development and acquisition of cell identity (122-124). However, rapid ILC activation relies on abilities of SRTFs to remodel de novo or latent enhancer landscapes for LDTF binding to their cognate DNA motifs in a sequencespecific manner $(50,125,126)$. ILCs can further undergo chromatin remodeling in the context of infection or inflammation $(127,128)$, a process involving sequence-specific recognition of SRTFs $(69,72,129)$. Interestingly, SRTF-activated de novo enhancer landscapes can further recruit LDTFs through a sequence-independent mechanism (72). Recent evidence indicates that TFs and co-activators with intrinsically disordered regions can form non-membrane bound condensates through weak multivalent protein-protein interactions, a dynamic process called phase separation (Figure 2A) (136-139). It remains to be determined whether the stimulation-dependent redistribution of LDTFs results from SRTF-mediated reorganization of phase separation, which contributes to biased loading of transcriptional machinery at super-enhancers (130-132).

\section{SUPER-ENHANCERS, A RESERVOIR OF TRANSCRIPTIONAL MACHINERY}

Super-enhancers or stretch-enhancers (SEs), in contrast to typical enhancers, denote complex REs marked by high density deposition of transcription factors and enhancer marks (Figure 2B); these features are often indicative of key cell identity and 


\section{A. Phase separation and loop extrusion}

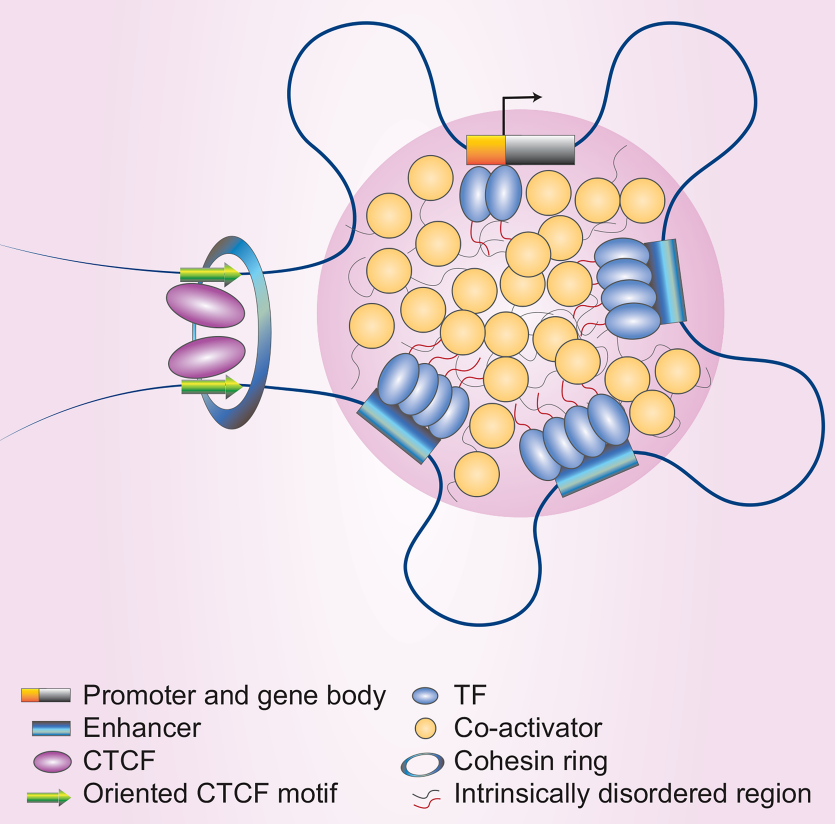

B. Typical enhancers

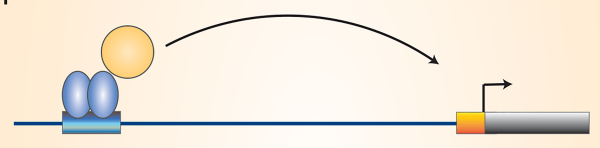

Super-enhancers

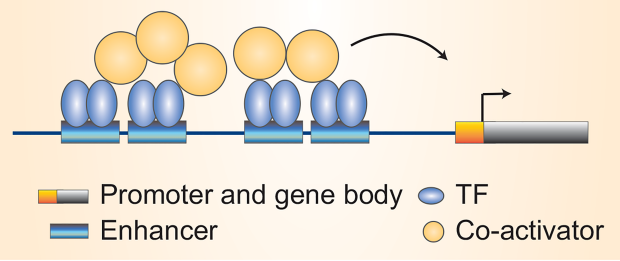

C. TAD formation

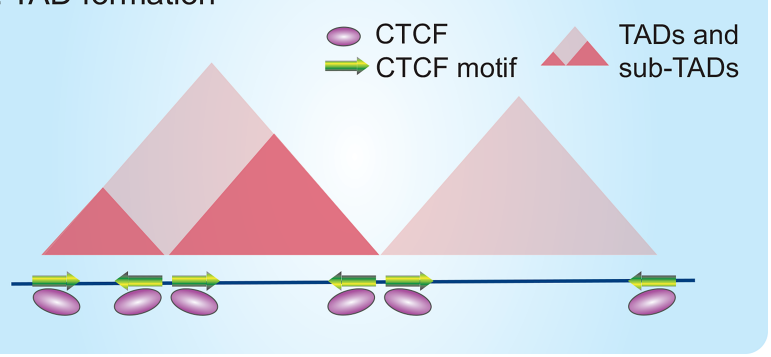

FIGURE 2 | A model of rapid gene induction in NK cells through higher-order chromatin architecture and remodeling. Many inducible genes in NK cells are associated with super-enhancers (SEs) that can be orderly modulated by multi-dimensional epigenetic mechanisms (72). (A) Phase separation. Phase separation occurs as a dynamic process in which transcription factors (TFs) and co-activators form non-membrane bound condensates through weak multivalent proteinprotein interactions of their intrinsically disordered region (130). Multi-loop hubs bring TF-bound regulatory elements (REs) and their target genes into close proximity to finetune gene expression. (B) Super-enhancers (SEs). SEs differ from typical enhancers as they recruit large numbers of TFs and transcriptional apparatus, including co-activators, to drive high magnitude of gene induction (130-132). (C) Topologically associating domains (TADs). Hi-C plots allow for visualization of threedimensional TADs and sub-TADs, which form during the cohesin-mediated loop extrusion process. Looping can occur between two convergently oriented CCCTCbinding factor (CTCF) sites, using a cohesin ring that extrudes DNAs as shown in (A) (2, 133-135).

disease-associated genes $(57,130,140-145)$. The construction of SEs involves remodeling chromatin landscapes induced by both intrinsic and extrinsic signals to recruit large numbers of TFs and transcriptional apparatus that contains co-activators including Mediator (Figures 2A, B) $(136,140)$. Along with the formation of multi-loop hubs, the result is that regulatory elements and their target genes are brought into close proximity $(130,146)$.

Delineation of SEs in Th cells using the active enhancerassociated protein histone acetyltransferase p300, revealed that the majority of Th lineage- and function-defining genes, including cytokines (Ifng, Il4, Ill0, Ill7a and Il17f) and key transcription factors (Tbx21, Gata3, Rorc and Rora), form SE structures during Th differentiation (57). These findings are consistent with multiple REs or locus control regions previously identified to be in close proximity to cytokine genes, including Ifng, Th2 cytokines (Il4-Il13-Il5) and the Il17a-Il17f locus $(67,147)$. Profiling SEs in human tonsillar ILCs and T cells by active enhancer mark histone 3 lysine 27 acetylation (H3K27Ac) clearly differentiates ILCs from Th cells (63).

Recent studies revealed that SE structures also are indicative of a high magnitude of gene induction. Within hours of cytokine stimulation, SRTFs such as NF- $\mathrm{KB}$ and STATs rapidly establish SEs at effector gene loci in innate immune cells (macrophages and
NK cells) to quickly provoke pro-inflammatory transcriptomes $(72,148-150)$. This process involves the recruitment of p300 to catalyze $\mathrm{H} 3 \mathrm{~K} 27 \mathrm{Ac}$ histone modification to both primed and de novo enhancers for prompt gene induction. In activated NK cells, de novo SEs are linked to highly-inducible genes, suggesting the rapid construction of SE structures boosts the magnitude of immediate transcriptional activity (Figure 2) (72).

\section{SOLUTION FOR PHYSICAL DISTANCING -NUCLEAR COMPARTMENTALIZATION AND HIGHER-ORDER CHROMATIN ARCHITECTURE}

Within the nucleus, the stretch of one-meter long DNA is segregated into active (euchromatin) and inactive (heterochromatin) territories, which are spatially organized into individual regulatory domains, designated topologically associating domains (TADs) $(5,151,152)$. TADs are formed via an extrusion process mediated by a cohesin ring and blocked by two convergently orientated CCCTC-binding factor (CTCF) sites (Figures 2A, C) $(2,133,134,153-158)$. CTCF is a chromatin 
organizer that dominates higher-order chromatin architecture and a multifunctional zinc finger TF that functions as an activator, a repressor or an insulator depending on co-localized molecules and how the chromatins are looped $(135,159)$.

Although most TADs are largely invariant across cell types, TADs and nested sub-TADs may also be cell-type specific, and thus underlie cell identity and discrete functions $(151,160)$. Even though CTCF is ubiquitously expressed and constitutively occupies TAD boundaries across different cell types (135), dynamic enhancer-promoter interactions and selective CTCF deposition at cell type-specific genes does occur. The CTCFcohesin-mediated 3D chromatin architecture dominates many biological processes including regulation of key cytokines. Global CTCF deficiency leads to impaired IFN- $\gamma$ and Th2 cytokine production in Th1 and Th2 cells, respectively $(161,162)$.

Other TFs also actively control chromatin topology. In Th1 cells, T-bet coordinates with CTCF to regulate Ifng locus $3 \mathrm{D}$ structure and full expression capacity (161). Crystal structure studies indicate that the T-bet DNA binding domain forms a dimer that allows T-bet to bind two independent DNA motifs distal from each other, suggesting the role of T-bet in loop formation (163). IL-2-mediated STAT5 activation also reconstruct $\mathrm{T}$ cell regulomes by remodeling SE landscapes and $3 \mathrm{D}$ regulatory domains that facilitate induction of IL-2 target genes (164). Dissecting the specific and dynamic roles of LDTFs and SDTFs in higher-order chromatin architecture in resting and activated ILCs will have important implications for understanding ILC gene regulation in health and disease.

\section{NON-CODING RNAS IN LYMPHOCYTE REGULATION}

Short non-coding RNAs, including microRNAs (miRNAs), as well as long non-coding RNAs (lncRNAs), including circular RNAs (circRNAs), are key players in post-transcriptional regulation and chromatin remodeling in innate and adaptive lymphocytes (165, 166). Mechanistically, lineage-specific miRNAs and lncRNAs are linked to super-enhancers and can control target genes in cis or in trans (167-170). For example, miR-29 directly regulates IFN- $\gamma$ production in $\mathrm{NK}, \mathrm{CD}^{+}$and $\mathrm{CD}^{+} \mathrm{T}$ cells by targeting IFN- $\gamma$ mRNA or indirectly via suppression of LDTFs EOMES and T-bet $(171,172)$. Other miRNAs including miR-155 and miR-17 92 promote Th1 immunity (173-176). Interestingly, miR-17 92 also promotes Th2 immunity in asthma affected airways (177), pointing to complex, less well-understood functions. In ILC1s, miR-142 plays a central role in IL-15-mediated NK cell survival, trafficking, homeostasis and defense against viral infection (178). Deficiency of miR-142 led to aberrant ILC1-like cell accumulation, potentially driven by TGF- $\beta$.

lncRNAs are critical for $\mathrm{CD}^{+}(179,180)$ and $\mathrm{CD}^{+} \mathrm{T}$ cell differentiation $(181,182)$. The Ifng locus itself is positively regulated by the lncRNA Ifng-asl (also known as NeST or Tmevpg1) as a mechanism to enhance Ifng expression in Th1 cells (183-186). The expression of Ifng-as 1 is dependent on remodeling of the proximal and distal enhancers by T-bet, recruiting TFs NF- $\mathrm{KB}$ and Ets1 to drive Ifng-as1 transcription (187). Ifng-as 1 is capable of engaging the chromatin modifying enzyme WDR5 that alters histone 3 methylation at the Ifng locus (184). Deletion of Ifng-as1, within the Ifng extended locus, led to disruption of chromatin organization and reduced Ifng expression, indicating its role in maintenance of the chromatin architecture of the Ifng extended locus. This was in part due to the deletion of a critical CTCF site that acted as a functional insulator (183).

lncRNAs can also modulate ILC development and function. For instance, the ILC1-specific lncRNA Rroid promotes the expression of $I d 2$, a transcription regulator that represses adaptive lymphocyte cell fate, and is essential for ILC1 development (188). The lncRNA $\ln c K d m 2 b$ is highly expressed in ILC3s and plays a key role in ILC3 maintenance through activation of the TF Zfp292 (189). On the other hand, the circRNA circKcnt2 inhibits Batf expression, which results in inhibition of ILC3 activation and IL-17 expression (190). Exactly how these IncRNAs precisely exert their effects and whether these mechanisms are conserved between innate and adaptive lymphocytes, however, remains unclear.

\section{CONCLUDING REMARKS}

Regulation of key cell identity and cytokine genes in lymphocytes requires carefully orchestrated epigenetic mechanisms and remodeling of the chromatin landscape by transcription factors (LDTFs and SRTFs), super-enhancers, TAD formation, CTCFanchored loops and non-coding RNAs. Exploration of these avenues in both local tissue and systemic environments holds promise in furthering our understanding of ILC and T cell regulomes. Several fundamental questions remain: how are nuclear compartmentalization and phase separation altered during lymphocyte development and activation? How do LDTFs and other co-activators developmentally shape and maintain immune cell regulomes? How do divergent chromatin landscapes respond to distinct pathogen invasion? What are the roles of SRTFs in the redistribution of transcriptional apparatus to mount an adequate immune response? How do super-enhancers coordinate different TFs and co-activators in the $3 \mathrm{D}$ space to direct final transcriptional output?

The rapid improvement in genome-wide epigenomic and single-cell transcriptomic profiling has provided a new angle to view global chromatin landscapes and transcriptional networks, even in rare populations such as ILCs. However, we are still yet to fully understand how novel key factors (DNAs, RNAs and proteins) asymmetrically distribute in the nuclei and physically interplay with each other in a context-dependent manner. The potential of newly developed techniques in the fields of molecular biology, fixed-cell microscopy, live-cell imaging, cryo-EM and genome editing may help to further our understanding. We are rapidly emerging into an era of epigenomic research that will allow us to decipher the mechanisms for lineage commitment and cytokine regulation in detail. Ultimately, we seek to identify key factors, signaling pathways or epigenetic modulations that can be 
targeted to prevent and/or control lymphocyte-mediated inflammation in diseases.

\section{AUTHOR CONTRIBUTIONS:}

H-YS conceived and wrote the first draft of the manuscript. NF and GS wrote sections of the manuscript and drafted the figures. JJO, NF, and GS reviewed and revised the text and figures. All

\section{REFERENCES}

1. Zheng $\mathrm{H}$, Xie $\mathrm{W}$. The role of 3D genome organization in development and cell differentiation. Nat Rev Mol Cell Biol (2019) 20:535-50. doi: 10.1038/ s41580-019-0132-4

2. Rowley MJ, Corces VG. Organizational principles of 3D genome architecture. Nat Rev Genet (2018) 19:789-800. doi: 10.1038/s41576-0180060-8

3. Consortium EP, Moore JE, Purcaro MJ, Pratt HE, Epstein CB, Shoresh N, et al. Expanded encyclopaedias of DNA elements in the human and mouse genomes. Nature (2020) 583:699-710. doi: 10.1038/s41586-020-2493-4

4. Van Bortle K, Corces VG. Nuclear organization and genome function. Annu Rev Cell Dev Biol (2012) 28:163-87. doi: 10.1146/annurev-cellbio-101011155824

5. Hnisz D, Day DS, Young RA. Insulated Neighborhoods: Structural and Functional Units of Mammalian Gene Control. Cell (2016) 167:1188-200. doi: 10.1016/j.cell.2016.10.024

6. Heinz S, Romanoski CE, Benner C, Glass CK. The selection and function of cell type-specific enhancers. Nat Rev Mol Cell Biol (2015) 16:144-54. doi: 10.1038/nrm3949

7. Spits H, Artis D, Colonna M, Diefenbach A, Di Santo JP, Eberl G, et al. Innate lymphoid cells-a proposal for uniform nomenclature. Nat Rev Immunol (2013) 13:145-9. doi: 10.1038/nri3365

8. Shih HY, Sciume G, Poholek AC, Vahedi G, Hirahara K, Villarino AV, et al. Transcriptional and epigenetic networks of helper $\mathrm{T}$ and innate lymphoid cells. Immunol Rev (2014) 261:23-49. doi: 10.1111/imr.12208

9. Colonna M. Innate Lymphoid Cells: Diversity, Plasticity, and Unique Functions in Immunity. Immunity (2018) 48:1104-17. doi: 10.1016/ j.immuni.2018.05.013

10. Vivier E, Artis D, Colonna M, Diefenbach A, Di Santo JP, Eberl G, et al. Innate Lymphoid Cells: 10 Years On. Cell (2018) 174:1054-66. doi: 10.1016/ j.cell.2018.07.017

11. Cherrier DE, Serafini N, Di Santo JP. Innate Lymphoid Cell Development: A T Cell Perspective. Immunity (2018) 48:1091-103. doi: 10.1016/ j.immuni.2018.05.010

12. De Obaldia ME, Bhandoola A. Transcriptional regulation of innate and adaptive lymphocyte lineages. Annu Rev Immunol (2015) 33:607-42. doi: 10.1146/annurev-immunol-032414-112032

13. Fang D, Zhu J. Dynamic balance between master transcription factors determines the fates and functions of $\mathrm{CD} 4 \mathrm{~T}$ cell and innate lymphoid cell subsets. J Exp Med (2017) 214:1861-76. doi: 10.1084/jem.20170494

14. Huang Q, Belz GT. Parallel worlds of the adaptive and innate immune cell networks. Curr Opin Immunol (2019) 58:53-9. doi: 10.1016/j.coi. 2019.04.008

15. Harsha Krovi S, Zhang J, Michaels-Foster MJ, Brunetti T, Loh L, ScottBrowne J, et al. Thymic iNKT single cell analyses unmask the common developmental program of mouse innate T cells. Nat Commun (2020) 11:6238. doi: 10.1038/s41467-020-20073-8

16. Engel I, Seumois G, Chavez L, Samaniego-Castruita D, White B, Chawla A, et al. Innate-like functions of natural killer $\mathrm{T}$ cell subsets result from highly divergent gene programs. Nat Immunol (2016) 17:728-39. doi: 10.1038/ ni. 3437

17. Annunziato F, Romagnani C, Romagnani S. The 3 major types of innate and adaptive cell-mediated effector immunity. J Allergy Clin Immunol (2015) 135:626-35. doi: 10.1016/j.jaci.2014.11.001 authors contributed to the article and approved the submitted version.

\section{FUNDING}

This review is supported by the NEI Intramural Research Program fund (ZIAEY000569-01).

18. Diefenbach A, Colonna M, Koyasu S. Development, differentiation, and diversity of innate lymphoid cells. Immunity (2014) 41:354-65. doi: 10.1016/ j.immuni.2014.09.005

19. Klose CS, Artis D. Innate lymphoid cells as regulators of immunity, inflammation and tissue homeostasis. Nat Immunol (2016) 17:765-74 doi: $10.1038 /$ ni.3489

20. Cella M, Miller H, Song C. Beyond NK cells: the expanding universe of innate lymphoid cells. Front Immunol (2014) 5:282. doi: 10.3389/ fimmu.2014.00282

21. Heinz S, Glass CK. Roles of lineage-determining transcription factors in establishing open chromatin: lessons from high-throughput studies. Curr Top Microbiol Immunol (2012) 356:1-15. doi: 10.1007/82_2011_142

22. Zaret KS, Carroll JS. Pioneer transcription factors: establishing competence for gene expression. Genes Dev (2011) 25:2227-41. doi: 10.1101/gad. 176826.111

23. Pokrovskii M, Hall JA, Ochayon DE, Yi R, Chaimowitz NS, Seelamneni H, et al. Characterization of Transcriptional Regulatory Networks that Promote and Restrict Identities and Functions of Intestinal Innate Lymphoid Cells. Immunity (2019) 51:185-97.e6. doi: 10.1016/ j.immuni.2019.06.001

24. Intlekofer AM, Takemoto N, Wherry EJ, Longworth SA, Northrup JT, Palanivel VR, et al. Effector and memory CD8+ T cell fate coupled by Tbet and eomesodermin. Nat Immunol (2005) 6:1236-44. doi: 10.1038/ni1268

25. Pritchard GH, Kedl RM, Hunter CA. The evolving role of T-bet in resistance to infection. Nat Rev Immunol (2019) 19:398-410. doi: 10.1038/s41577-0190145-4

26. Gray SM, Kaech SM, Staron MM. The interface between transcriptional and epigenetic control of effector and memory CD8(+) T-cell differentiation. Immunol Rev (2014) 261:157-68. doi: 10.1111/imr.12205

27. Kaech SM, Cui W. Transcriptional control of effector and memory CD8+ T cell differentiation. Nat Rev Immunol (2012) 12:749-61. doi: 10.1038/ nri3307

28. Pearce EL, Mullen AC, Martins GA, Krawczyk CM, Hutchins AS, Zediak VP, et al. Control of effector CD8+ T cell function by the transcription factor Eomesodermin. Science (2003) 302:1041-3. doi: 10.1126/science.1090148

29. Sun JC, Lanier LL. NK cell development, homeostasis and function: parallels with CD8(+) T cells. Nat Rev Immunol (2011) 11:645-57. doi: 10.1038/ nri3044

30. Gordon SM, Chaix J, Rupp LJ, Wu J, Madera S, Sun JC, et al. The transcription factors T-bet and Eomes control key checkpoints of natural killer cell maturation. Immunity (2012) 36:55-67. doi: 10.1016/ j.immuni.2011.11.016

31. Daussy C, Faure F, Mayol K, Viel S, Gasteiger G, Charrier E, et al. T-bet and Eomes instruct the development of two distinct natural killer cell lineages in the liver and in the bone marrow. J Exp Med (2014) 211:563-77. doi: 10.1084/jem.20131560

32. Zhang J, Marotel M, Fauteux-Daniel S, Mathieu AL, Viel S, Marcais A, et al. T-bet and Eomes govern differentiation and function of mouse and human NK cells and ILC1. Eur J Immunol (2018) 48:738-50. doi: 10.1002/ eji.201747299

33. Lazarevic V, Glimcher LH, Lord GM. T-bet: a bridge between innate and adaptive immunity. Nat Rev Immunol (2013) 13:777-89. doi: 10.1038/ nri3536

34. Mjosberg J, Bernink J, Golebski K, Karrich JJ, Peters CP, Blom B, et al. The transcription factor GATA3 is essential for the function of human type 2 
innate lymphoid cells. Immunity (2012) 37:649-59. doi: 10.1016/ j.immuni.2012.08.015

35. Hoyler T, Klose CS, Souabni A, Turqueti-Neves A, Pfeifer D, Rawlins EL, et al. The transcription factor GATA-3 controls cell fate and maintenance of type 2 innate lymphoid cells. Immunity (2012) 37:634-48. doi: 10.1016/ j.immuni.2012.06.020

36. Tindemans I, Serafini N, Di Santo JP, Hendriks RW. GATA-3 function in innate and adaptive immunity. Immunity (2014) 41:191-206. doi: 10.1016/ j.immuni.2014.06.006

37. Ivanov II, McKenzie BS, Zhou L, Tadokoro CE, Lepelley A, Lafaille JJ, et al. The orphan nuclear receptor RORgammat directs the differentiation program of proinflammatory IL-17+ T helper cells. Cell (2006) 126 (6):1121-33, 126. doi: 10.1016/j.cell.2006.07.035

38. Cording S, Medvedovic J, Cherrier M, Eberl G. Development and regulation of RORgammat(+) innate lymphoid cells. FEBS Lett (2014) 588:4176-81. doi: 10.1016/j.febslet.2014.03.034

39. Serafini N, Vosshenrich CA, Di Santo JP. Transcriptional regulation of innate lymphoid cell fate. Nat Rev Immunol (2015) 15:415-28. doi: 10.1038/ nri3855

40. Wu C. The 5' ends of Drosophila heat shock genes in chromatin are hypersensitive to DNase I. Nature (1980) 286:854-60. doi: 10.1038/286854a0

41. Hebbes TR, Clayton AL, Thorne AW, Crane-Robinson C. Core histone hyperacetylation co-maps with generalized DNase I sensitivity in the chicken beta-globin chromosomal domain. EMBO J (1994) 13(8):1823-30. doi: 10.1002/j.1460-2075.1994.tb06451.x

42. Dekker J, Rippe K, Dekker M, Kleckner N. Capturing chromosome conformation. Science (2002) 295:1306-11. doi: 10.1126/science.1067799

43. Crawford GE, Holt IE, Mullikin JC, Tai D, Blakesley R, Bouffard G, et al. Identifying gene regulatory elements by genome-wide recovery of DNase hypersensitive sites. Proc Natl Acad Sci USA (2004) 101:992-7. doi: 10.1073/ pnas. 0307540100

44. Johnson DS, Mortazavi A, Myers RM, Wold B. Genome-wide mapping of in vivo protein-DNA interactions. Science (2007) 316:1497-502. doi: 10.1126/ science. 1141319

45. Barski A, Cuddapah S, Cui K, Roh TY, Schones DE, Wang Z, et al. Highresolution profiling of histone methylations in the human genome. Cell (2007) 129:823-37. doi: 10.1016/j.cell.2007.05.009

46. Mikkelsen TS, Ku M, Jaffe DB, Issac B, Lieberman E, Giannoukos G, et al. Genome-wide maps of chromatin state in pluripotent and lineagecommitted cells. Nature (2007) 448:553-60. doi: 10.1038/nature06008

47. Kieffer-Kwon KR, Tang Z, Mathe E, Qian J, Sung MH, Li G, et al. Interactome maps of mouse gene regulatory domains reveal basic principles of transcriptional regulation. Cell (2013) 155:1507-20. doi: 10.1016/j.cell.2013.11.039

48. Chaudhri VK, Dienger-Stambaugh K, Wu Z, Shrestha M, Singh H. Charting the cis-regulome of activated B cells by coupling structural and functional genomics. Nat Immunol (2020) 21:210-20. doi: 10.1038/s41590-019-0565-0

49. Smale ST, Natoli G. Transcriptional control of inflammatory responses. Cold Spring Harb Perspect Biol (2014) 6:a016261. doi: 10.1101/cshperspect. a016261

50. Glass CK, Natoli G. Molecular control of activation and priming in macrophages. Nat Immunol (2016) 17:26-33. doi: 10.1038/ni.3306

51. Singh H, Khan AA, Dinner AR. Gene regulatory networks in the immune system. Trends Immunol (2014) 35:211-8. doi: 10.1016/j.it.2014.03.006

52. Zhang JA, Mortazavi A, Williams BA, Wold BJ, Rothenberg EV. Dynamic transformations of genome-wide epigenetic marking and transcriptional control establish T cell identity. Cell (2012) 149:467-82. doi: 10.1016/ j.cell.2012.01.056

53. Schoenborn JR, Dorschner MO, Sekimata M, Santer DM, Shnyreva M, Fitzpatrick DR, et al. Comprehensive epigenetic profiling identifies multiple distal regulatory elements directing transcription of the gene encoding interferon-gamma. Nat Immunol (2007) 8:732-42. doi: 10.1038/ni1474

54. Wei G, Wei L, Zhu J, Zang C, Hu-Li J, Yao Z, et al. Global mapping of H3K4me3 and H3K27me3 reveals specificity and plasticity in lineage fate determination of differentiating CD4+ T cells. Immunity (2009) 30:155-67. doi: 10.1016/j.immuni.2008.12.009

55. Hawkins RD, Larjo A, Tripathi SK, Wagner U, Luu Y, Lonnberg T, et al. Global chromatin state analysis reveals lineage-specific enhancers during the initiation of human $\mathrm{T}$ helper 1 and $\mathrm{T}$ helper 2 cell polarization. Immunity (2013) 38:1271-84. doi: 10.1016/j.immuni.2013.05.011

56. Vahedi G, Takahashi H, Nakayamada S, Sun HW, Sartorelli V, Kanno Y, et al. STATs shape the active enhancer landscape of T cell populations. Cell (2012) 151:981-93. doi: 10.1016/j.cell.2012.09.044

57. Vahedi G, Kanno Y, Furumoto Y, Jiang K, Parker SC, Erdos MR, et al. Superenhancers delineate disease-associated regulatory nodes in T cells. Nature (2015) 520:558-62. doi: 10.1038/nature14154

58. Wei L, Vahedi G, Sun HW, Watford WT, Takatori H, Ramos HL, et al. Discrete roles of STAT4 and STAT6 transcription factors in tuning epigenetic modifications and transcription during $\mathrm{T}$ helper cell differentiation. Immunity (2010) 32:840-51. doi: 10.1016/j.immuni. 2010.06.003

59. Vieira Braga FA, Teichmann SA, Chen X. Genetics and immunity in the era of single-cell genomics. Hum Mol Genet (2016) 25:R141-8. doi: 10.1093/ hmg/ddw192

60. Buenrostro JD, Giresi PG, Zaba LC, Chang HY, Greenleaf WJ. Transposition of native chromatin for fast and sensitive epigenomic profiling of open chromatin, DNA-binding proteins and nucleosome position. Nat Methods (2013) 10:1213-8. doi: 10.1038/nmeth.2688

61. Brind'Amour J, Liu S, Hudson M, Chen C, Karimi MM, Lorincz MC. An ultra-low-input native ChIP-seq protocol for genome-wide profiling of rare cell populations. Nat Commun (2015) 6:6033. doi: 10.1038/ncomms7033

62. Lara-Astiaso D, Weiner A, Lorenzo-Vivas E, Zaretsky I, Jaitin DA, David E, et al. Immunogenetics. Chromatin state dynamics during blood formation. Science (2014) 345:943-9. doi: 10.1126/science.1256271

63. Koues OI, Collins PL, Cella M, Robinette ML, Porter SI, Pyfrom SC, et al. Distinct Gene Regulatory Pathways for Human Innate versus Adaptive Lymphoid Cells. Cell (2016) 165:1134-46. doi: 10.1016/j.cell.2016. 04.014

64. Shih HY, Sciume G, Mikami Y, Guo L, Sun HW, Brooks SR, et al Developmental Acquisition of Regulomes Underlies Innate Lymphoid Cell Functionality. Cell (2016) 165:1120-33. doi: 10.1016/j.cell.2016.04.029

65. Gury-BenAri M, Thaiss CA, Serafini N, Winter DR, Giladi A, Lara-Astiaso $\mathrm{D}$, et al. The Spectrum and Regulatory Landscape of Intestinal Innate Lymphoid Cells Are Shaped by the Microbiome. Cell (2016) 166:123146.e13. doi: 10.1016/j.cell.2016.07.043

66. Collins PL, Cella M, Porter SI, Li S, Gurewitz GL, Hong HS, et al. Gene Regulatory Programs Conferring Phenotypic Identities to Human NK Cells. Cell (2019) 176:348-60.e12. doi: 10.1016/j.cell.2018.11.045

67. Wilson CB, Rowell E, Sekimata M. Epigenetic control of T-helper-cell differentiation. Nat Rev Immunol (2009) 9:91-105. doi: 10.1038/nri2487

68. Stergachis AB, Neph S, Sandstrom R, Haugen E, Reynolds AP, Zhang M, et al. Conservation of trans-acting circuitry during mammalian regulatory evolution. Nature (2014) 515:365-70. doi: 10.1038/nature13972

69. Lau CM, Adams NM, Geary CD, Weizman OE, Rapp M, Pritykin Y, et al. Epigenetic control of innate and adaptive immune memory. Nat Immunol (2018) 19:963-72. doi: 10.1038/s41590-018-0176-1

70. Schlums H, Cichocki F, Tesi B, Theorell J, Beziat V, Holmes TD, et al Cytomegalovirus infection drives adaptive epigenetic diversification of NK cells with altered signaling and effector function. Immunity (2015) 42:44356. doi: 10.1016/j.immuni.2015.02.008

71. O'Sullivan TE, Sun JC, Lanier LL. Natural Killer Cell Memory. Immunity (2015) 43:634-45. doi: 10.1016/j.immuni.2015.09.013

72. Sciume G, Mikami Y, Jankovic D, Nagashima H, Villarino AV, Morrison T, et al. Rapid Enhancer Remodeling and Transcription Factor Repurposing Enable High Magnitude Gene Induction upon Acute Activation of NK Cells. Immunity (2020) 53:745-58.e4. doi: 10.1016/j.immuni.2020.09.008

73. Kiner E, Willie E, Vijaykumar B, Chowdhary K, Schmutz H, Chandler J, et al. Gut CD4(+) T cell phenotypes are a continuum molded by microbes, not by TH archetypes. Nat Immunol (2021) 22:216-28. doi: 10.1038/s41590020-00836-7

74. Iwafuchi-Doi M, Zaret KS. Pioneer transcription factors in cell reprogramming. Genes Dev (2014) 28:2679-92. doi: 10.1101/gad.253443.114

75. Heinz S, Benner C, Spann N, Bertolino E, Lin YC, Laslo P, et al. Simple combinations of lineage-determining transcription factors prime cisregulatory elements required for macrophage and B cell identities. Mol Cell (2010) 38:576-89. doi: 10.1016/j.molcel.2010.05.004 
76. Harly C, Kenney D, Ren G, Lai B, Raabe T, Yang Q, et al. The transcription factor TCF-1 enforces commitment to the innate lymphoid cell lineage. Nat Immunol (2019) 20:1150-60. doi: 10.1038/s41590-019-0445-7

77. Yang Q, Li F, Harly C, Xing S, Ye L, Xia X, et al. TCF-1 upregulation identifies early innate lymphoid progenitors in the bone marrow. Nat Immunol (2015) 16:1044-50. doi: 10.1038/ni.3248

78. Raghu D, Xue HH, Mielke LA. Control of Lymphocyte Fate, Infection, and Tumor Immunity by TCF-1. Trends Immunol (2019) 40:1149-62. doi: 10.1016/j.it.2019.10.006

79. Spits H. TOX sets the stage for innate lymphoid cells. Nat Immunol (2015) 16:594-5. doi: 10.1038/ni.3177

80. Seehus CR, Kaye J. The Role of TOX in the Development of Innate Lymphoid Cells. Mediators Inflammation (2015) 2015:243868. doi: $10.1155 / 2015 / 243868$

81. Seehus CR, Aliahmad P, de la Torre B, Iliev ID, Spurka L, Funari VA, et al. The development of innate lymphoid cells requires TOX-dependent generation of a common innate lymphoid cell progenitor. Nat Immunol (2015) 16:599-608. doi: 10.1038/ni.3168

82. Califano D, Cho JJ, Uddin MN, Lorentsen KJ, Yang Q, Bhandoola A, et al. Transcription Factor Bcl11b Controls Identity and Function of Mature Type 2 Innate Lymphoid Cells. Immunity (2015) 43:354-68. doi: 10.1016/ j.immuni.2015.07.005

83. Yu Y, Wang C, Clare S, Wang J, Lee SC, Brandt C, et al. The transcription factor Bcll1b is specifically expressed in group 2 innate lymphoid cells and is essential for their development. J Exp Med (2015) 212:865-74. doi: 10.1084/ jem.20142318

84. Yu Y, Tsang JC, Wang C, Clare S, Wang J, Chen X, et al. Single-cell RNA-seq identifies a PD-1(hi) ILC progenitor and defines its development pathway. Nature (2016) 539:102-6. doi: 10.1038/nature20105

85. Miyamoto C, Kojo S, Yamashita M, Moro K, Lacaud G, Shiroguchi K, et al. Runx/Cbfbeta complexes protect group 2 innate lymphoid cells from exhausted-like hyporesponsiveness during allergic airway inflammation. Nat Commun (2019) 10:447. doi: 10.1038/s41467-019-08932-5

86. Ebihara T, Song C, Ryu SH, Plougastel-Douglas B, Yang L, Levanon D, et al. Runx3 specifies lineage commitment of innate lymphoid cells. Nat Immunol (2015) 16:1124-33. doi: 10.1038/ni.3272

87. Zook EC, Kee BL. Development of innate lymphoid cells. Nat Immunol (2016) 17:775-82. doi: 10.1038/ni.3481

88. Zhu J. GATA3 Regulates the Development and Functions of Innate Lymphoid Cell Subsets at Multiple Stages. Front Immunol (2017) 8:1571. doi: 10.3389/fimmu.2017.01571

89. Zhong C, Zheng M, Cui K, Martins AJ, Hu G, Li D, et al. Differential Expression of the Transcription Factor GATA3 Specifies Lineage and Functions of Innate Lymphoid Cells. Immunity (2020) 52:83-95.e4. doi: 10.1016/j.immuni.2019.12.001

90. Yagi R, Zhong C, Northrup DL, Yu F, Bouladoux N, Spencer S, et al. The transcription factor GATA3 is critical for the development of all IL-7Ralphaexpressing innate lymphoid cells. Immunity (2014) 40:378-88. doi: 10.1016/ j.immuni.2014.01.012

91. Zhong C, Cui K, Wilhelm C, Hu G, Mao K, Belkaid Y, et al. Group 3 innate lymphoid cells continuously require the transcription factor GATA-3 after commitment. Nat Immunol (2016) 17:169-78. doi: 10.1038/ni.3318

92. Johnson JL, Georgakilas G, Petrovic J, Kurachi M, Cai S, Harly C, et al. Lineage-Determining Transcription Factor TCF-1 Initiates the Epigenetic Identity of T Cells. Immunity (2018) 48:243-57.e10. doi: 10.1016/ j.immuni.2018.01.012

93. Hu G, Cui K, Fang D, Hirose S, Wang X, Wangsa D, et al. Transformation of Accessible Chromatin and 3D Nucleome Underlies Lineage Commitment of Early T Cells. Immunity (2018) 48:227-42.e8. doi: 10.1016/j.immuni.2018.01.013

94. Hosokawa H, Romero-Wolf M, Yang Q, Motomura Y, Levanon D, Groner Y, et al. Cell type-specific actions of Bcl11b in early T-lineage and group 2 innate lymphoid cells. J Exp Med (2020) 217(1):e20190972. doi: 10.1084/jem.20190972

95. Xu W, Domingues RG, Fonseca-Pereira D, Ferreira M, Ribeiro H, LopezLastra S, et al. NFIL3 orchestrates the emergence of common helper innate lymphoid cell precursors. Cell Rep (2015) 10:2043-54. doi: 10.1016/ j.celrep.2015.02.057

96. Yu X, Wang Y, Deng M, Li Y, Ruhn KA, Zhang CC, et al. The basic leucine zipper transcription factor NFIL3 directs the development of a common innate lymphoid cell precursor. Elife (2014) 3:e04406. doi: 10.7554/ eLife.04406

97. Seillet C, Rankin LC, Groom JR, Mielke LA, Tellier J, Chopin M, et al. Nfil3 is required for the development of all innate lymphoid cell subsets. J Exp Med (2014) 211:1733-40. doi: 10.1084/jem.20140145

98. Geiger TL, Abt MC, Gasteiger G, Firth MA, O’Connor MH, Geary CD, et al. $\mathrm{Nfil} 3$ is crucial for development of innate lymphoid cells and host protection against intestinal pathogens. J Exp Med (2014) 211:1723-31. doi: 10.1084/ jem.20140212

99. Male V, Nisoli I, Kostrzewski T, Allan DS, Carlyle JR, Lord GM, et al. The transcription factor E4bp4/Nfil3 controls commitment to the NK lineage and directly regulates Eomes and Id2 expression. J Exp Med (2014) 211:63542. doi: $10.1084 /$ jem. 20132398

100. Gascoyne DM, Long E, Veiga-Fernandes H, de Boer J, Williams O, Seddon B, et al. The basic leucine zipper transcription factor E4BP4 is essential for natural killer cell development. Nat Immunol (2009) 10:1118-24. doi: $10.1038 /$ ni. 1787

101. Verykokakis M, Zook EC, Kee BL. ID'ing innate and innate-like lymphoid cells. Immunol Rev (2014) 261:177-97. doi: 10.1111/imr.12203

102. Zook EC, Li ZY, Xu Y, de Pooter RF, Verykokakis M, Beaulieu A, et al. Transcription factor ID2 prevents $\mathrm{E}$ proteins from enforcing a naive $\mathrm{T}$ lymphocyte gene program during NK cell development. Sci Immunol (2018) 3(22):eaao2139. doi: 10.1126/sciimmunol.aao2139

103. Cherrier M, Sawa S, Eberl G. Notch, Id2, and RORgammat sequentially orchestrate the fetal development of lymphoid tissue inducer cells. J Exp Med (2012) 209:729-40. doi: 10.1084/jem.20111594

104. Constantinides MG, McDonald BD, Verhoef PA, Bendelac A. A committed precursor to innate lymphoid cells. Nature (2014) 508:397-401. doi: 10.1038/ nature 13047

105. Klose CSN, Flach M, Mohle L, Rogell L, Hoyler T, Ebert K, et al. Differentiation of type 1 ILCs from a common progenitor to all helper-like innate lymphoid cell lineages. Cell (2014) 157:340-56. doi: 10.1016/ j.cell.2014.03.030

106. Xu W, Cherrier DE, Chea S, Vosshenrich C, Serafini N, Petit M, et al. An Id2 (RFP)-reporter mouse redefines innate lymphoid cell precursor potentials. Immunity (2019) 50:1054-68.e3. doi: 10.1016/j.immuni.2019.02.022

107. McGinty JW, von Moltke J. A three course menu for ILC and bystander T cell activation. Curr Opin Immunol (2020) 62:15-21. doi: 10.1016/j.coi.2019.11.005

108. Zhu J, Yamane H, Paul WE. Differentiation of effector CD4 T cell populations $\left(^{*}\right)$. Annu Rev Immunol (2010) 28:445-89. doi: 10.1146/ annurev-immunol-030409-101212

109. Bernink JH, Krabbendam L, Germar K, de Jong E, Gronke K, Kofoed-Nielsen M, et al. Interleukin-12 and -23 Control Plasticity of CD127(+) Group 1 and Group 3 Innate Lymphoid Cells in the Intestinal Lamina Propria. Immunity (2015) 43:146-60. doi: 10.1016/j.immuni.2015.06.019

110. O’Sullivan TE, Rapp M, Fan X, Weizman OE, Bhardwaj P, Adams NM, et al. Adipose-Resident Group 1 Innate Lymphoid Cells Promote ObesityAssociated Insulin Resistance. Immunity (2016) 45:428-41. doi: 10.1016/ j.immuni.2016.06.016

111. Symowski C, Voehringer D. Th2 cell-derived IL-4/IL-13 promote ILC2 accumulation in the lung by ILC2-intrinsic STAT6 signaling in mice. Eur J Immunol (2019) 49:1421-32. doi: 10.1002/eji.201948161

112. Motomura Y, Morita H, Moro K, Nakae S, Artis D, Endo TA, et al. Basophilderived interleukin- 4 controls the function of natural helper cells, a member of ILC2s, in lung inflammation. Immunity (2014) 40:758-71. doi: 10.1016/ j.immuni.2014.04.013

113. Kanhere A, Hertweck A, Bhatia U, Gokmen MR, Perucha E, Jackson I, et al. T-bet and GATA3 orchestrate Th1 and Th2 differentiation through lineagespecific targeting of distal regulatory elements. Nat Commun (2012) 3:1268. doi: $10.1038 /$ ncomms 2260

114. Cella M, Gamini R, Secca C, Collins PL, Zhao S, Peng V, et al. Subsets of ILC3-ILC1-like cells generate a diversity spectrum of innate lymphoid cells in human mucosal tissues. Nat Immunol (2019) 20:980-91. doi: 10.1038/ s41590-019-0425-y

115. Bal SM, Golebski K, Spits H. Plasticity of innate lymphoid cell subsets. Nat Rev Immunol (2020) 20:552-65. doi: 10.1038/s41577-020-0282-9

116. Doherty TA, Khorram N, Lund S, Mehta AK, Croft M, Broide DH. Lung type 2 innate lymphoid cells express cysteinyl leukotriene receptor 1, which 
regulates TH2 cytokine production. J Allergy Clin Immunol (2013) 132:20513. doi: $10.1016 /$ j.jaci.2013.03.048

117. von Moltke J, O’Leary CE, Barrett NA, Kanaoka Y, Austen KF, Locksley RM. Leukotrienes provide an NFAT-dependent signal that synergizes with IL-33 to activate ILC2s. J Exp Med (2017) 214:27-37. doi: 10.1084/jem.20161274

118. Lund SJ, Portillo A, Cavagnero K, Baum RE, Naji LH, Badrani JH, et al. Leukotriene C4 Potentiates IL-33-Induced Group 2 Innate Lymphoid Cell Activation and Lung Inflammation. J Immunol (2017) 199:1096-104. doi: 10.4049/jimmunol.1601569

119. Xue L, Salimi M, Panse I, Mjosberg JM, McKenzie AN, Spits H, et al. Prostaglandin D2 activates group 2 innate lymphoid cells through chemoattractant receptor-homologous molecule expressed on TH2 cells. J Allergy Clin Immunol (2014) 133:1184-94. doi: 10.1016/j.jaci.2013.10.056

120. Klose CSN, Mahlakoiv T, Moeller JB, Rankin LC, Flamar AL, Kabata H, et al. The neuropeptide neuromedin $\mathrm{U}$ stimulates innate lymphoid cells and type 2 inflammation. Nature (2017) 549:282-6. doi: 10.1038/nature23676

121. Wallrapp A, Riesenfeld SJ, Burkett PR, Abdulnour RE, Nyman J, Dionne D, et al. The neuropeptide NMU amplifies ILC2-driven allergic lung inflammation. Nature (2017) 549:351-6. doi: 10.1038/nature24029

122. Gotthardt D, Trifinopoulos J, Sexl V, Putz EM. JAK/STAT Cytokine Signaling at the Crossroad of NK Cell Development and Maturation. Front Immunol (2019) 10:2590. doi: 10.3389/fimmu.2019.02590

123. Stabile H, Scarno G, Fionda C, Gismondi A, Santoni A, Gadina M, et al. JAK/ STAT signaling in regulation of innate lymphoid cells: The gods before the guardians. Immunol Rev (2018) 286:148-59. doi: 10.1111/imr.12705

124. Villarino AV, Sciume G, Davis FP, Iwata S, Zitti B, Robinson GW, et al. Subset- and tissue-defined STAT5 thresholds control homeostasis and function of innate lymphoid cells. J Exp Med (2017) 214:2999-3014. doi: 10.1084/jem.20150907

125. Kaikkonen MU, Spann NJ, Heinz S, Romanoski CE, Allison KA, Stender JD, et al. Remodeling of the enhancer landscape during macrophage activation is coupled to enhancer transcription. Mol Cell (2013) 51:310-25. doi: 10.1016/ j.molcel.2013.07.010

126. Ostuni R, Piccolo V, Barozzi I, Polletti S, Termanini A, Bonifacio S, et al. Latent enhancers activated by stimulation in differentiated cells. Cell (2013) 152:157-71. doi: 10.1016/j.cell.2012.12.018

127. Rasid O, Chevalier C, Camarasa TM, Fitting C, Cavaillon JM, Hamon MA. H3K4me1 supports memory-like NK cells induced by systemic inflammation. Cell Rep (2019) 29:3933-45.e3. doi: 10.1016/j.celrep. 2019.11.043

128. Mikami Y, Scarno G, Zitti B, Shih HY, Kanno Y, Santoni A, et al. NCR(+) ILC3 maintain larger STAT4 reservoir via T-BET to regulate type 1 features upon IL-23 stimulation in mice. Eur J Immunol (2018) 48:1174-80. doi: 10.1002/eji.201847480

129. Madera S, Geary CD, Lau CM, Pikovskaya O, Reiner SL, Sun JC. Cutting edge: Divergent requirement of T-box transcription factors in effector and memory NK cells. J Immunol (2018) 200:1977-81. doi: 10.4049/ jimmunol.1700416

130. Hnisz D, Shrinivas K, Young RA, Chakraborty AK, Sharp PA. A Phase Separation Model for Transcriptional Control. Cell (2017) 169:13-23. doi: 10.1016/j.cell.2017.02.007

131. Sabari BR, Dall'Agnese A, Young RA. Biomolecular Condensates in the Nucleus. Trends Biochem Sci (2020) 45:961-77. doi: 10.1016/ j.tibs.2020.06.007

132. Shrinivas K, Sabari BR, Coffey EL, Klein IA, Boija A, Zamudio AV, et al. Enhancer Features that Drive Formation of Transcriptional Condensates. Mol Cell (2019) 75549-61:e7. doi: 10.1016/j.molcel.2019.07.009

133. Merkenschlager M, Nora EP. CTCF and Cohesin in Genome Folding and Transcriptional Gene Regulation. Annu Rev Genomics Hum Genet (2016) 17:17-43. doi: 10.1146/annurev-genom-083115-022339

134. Nora EP, Caccianini L, Fudenberg G, So K, Kameswaran V, Nagle A, et al. Molecular basis of CTCF binding polarity in genome folding. Nat Commun (2020) 11:5612. doi: 10.1038/s41467-020-19283-x

135. Ong CT, Corces VG. CTCF: an architectural protein bridging genome topology and function. Nat Rev Genet (2014) 15:234-46. doi: 10.1038/ nrg3663

136. Zamudio AV, Dall'Agnese A, Henninger JE, Manteiga JC, Afeyan LK, Hannett NM, et al. Mediator Condensates Localize Signaling Factors to
Key Cell Identity Genes. Mol Cell (2019) 76:753-66.e6. doi: 10.1016/ j.molcel.2019.08.016

137. Sabari BR, Dall'Agnese A, Boija A, Klein IA, Coffey EL, Shrinivas K, et al. Coactivator condensation at super-enhancers links phase separation and gene control. Science (2018) 361(6400):eaar3958. doi: 10.1126/ science.aar3958

138. Boija A, Klein IA, Sabari BR, Dall'Agnese A, Coffey EL, Zamudio AV, et al. Transcription Factors Activate Genes through the Phase-Separation Capacity of Their Activation Domains. Cell (2018) 175:1842-55.e16. doi: 10.1016/j.cell.2018.10.042

139. Cho WK, Spille JH, Hecht M, Lee C, Li C, Grube V, et al. Mediator and RNA polymerase II clusters associate in transcription-dependent condensates. Science (2018) 361:412-5. doi: 10.1126/science.aar4199

140. Whyte WA, Orlando DA, Hnisz D, Abraham BJ, Lin CY, Kagey MH, et al. Master transcription factors and mediator establish super-enhancers at key cell identity genes. Cell (2013) 153:307-19. doi: 10.1016/j.cell.2013.03.035

141. Hnisz D, Abraham BJ, Lee TI, Lau A, Saint-Andre V, Sigova AA, et al. Superenhancers in the control of cell identity and disease. Cell (2013) 155:934-47. doi: 10.1016/j.cell.2013.09.053

142. Chapuy B, McKeown MR, Lin CY, Monti S, Roemer MG, Qi J, et al. Discovery and characterization of super-enhancer-associated dependencies in diffuse large B cell lymphoma. Cancer Cell (2013) 24:777-90. doi: 10.1016/ j.ccr.2013.11.003

143. Loven J, Hoke HA, Lin CY, Lau A, Orlando DA, Vakoc CR, et al. Selective inhibition of tumor oncogenes by disruption of super-enhancers. Cell (2013) 153:320-34. doi: 10.1016/j.cell.2013.03.036

144. Parker SC, Stitzel ML, Taylor DL, Orozco JM, Erdos MR, Akiyama JA, et al. A. National Institutes of Health Intramural Sequencing Center Comparative Sequencing Program, N.C.S.P. Authors, Chromatin stretch enhancer states drive cell-specific gene regulation and harbor human disease risk variants. Proc Natl Acad Sci USA (2013) 110:17921-6. doi: 10.1073/pnas.1317023110

145. Afzali B, Gronholm J, Vandrovcova J, O’Brien C, Sun HW, Vanderleyden I, et al. $\mathrm{BACH} 2$ immunodeficiency illustrates an association between superenhancers and haploinsufficiency. Nat Immunol (2017) 18:813-23. doi: 10.1038/ni.3753

146. Witte S, O'Shea JJ, Vahedi G. Super-enhancers: Asset management in immune cell genomes. Trends Immunol (2015) 36:519-26. doi: 10.1016/ j.it.2015.07.005

147. Ansel KM, Djuretic I, Tanasa B, Rao A. Regulation of Th2 differentiation and Il4 locus accessibility. Annu Rev Immunol (2006) 24:607-56. doi: 10.1146/ annurev.immunol.23.021704.115821

148. Brown JD, Lin CY, Duan Q, Griffin G, Federation A, Paranal RM, et al. NFkappaB directs dynamic super enhancer formation in inflammation and atherogenesis. Mol Cell (2014) 56:219-31. doi: 10.1016/j.molcel.2014.08.024

149. Bojcsuk D, Nagy G, Balint BL. Inducible super-enhancers are organized based on canonical signal-specific transcription factor binding elements. Nucleic Acids Res (2017) 45:3693-706. doi: 10.1093/nar/gkw1283

150. Dey A, Yang W, Gegonne A, Nishiyama A, Pan R, Yagi R, et al. BRD4 directs hematopoietic stem cell development and modulates macrophage inflammatory responses. EMBO J (2019) 38:e100293. doi: 10.15252/ embj.2018100293

151. Stadhouders R, Filion GJ, Graf T. Transcription factors and 3D genome conformation in cell-fate decisions. Nature (2019) 569:345-54. doi: 10.1038/ s41586-019-1182-7

152. Dowen JM, Fan ZP, Hnisz D, Ren G, Abraham BJ, Zhang LN, et al. Control of cell identity genes occurs in insulated neighborhoods in mammalian chromosomes. Cell (2014) 159:374-87. doi: 10.1016/j.cell.2014.09.030

153. de Wit E, Vos ES, Holwerda SJ, Valdes-Quezada C, Verstegen MJ, Teunissen $\mathrm{H}$, et al. CTCF Binding Polarity Determines Chromatin Looping. Mol Cell (2015) 60:676-84. doi: 10.1016/j.molcel.2015.09.023

154. Rao SS, Huntley MH, Durand NC, Stamenova EK, Bochkov ID, Robinson JT, et al. A 3D map of the human genome at kilobase resolution reveals principles of chromatin looping. Cell (2014) 159:1665-80. doi: 10.1016/ j.cell.2014.11.021

155. Sanborn AL, Rao SS, Huang SC, Durand NC, Huntley MH, Jewett AI, et al. Chromatin extrusion explains key features of loop and domain formation in wild-type and engineered genomes. Proc Natl Acad Sci USA (2015) 112: E6456-65. doi: 10.1073/pnas.1518552112 
156. Busslinger GA, Stocsits RR, van der Lelij P, Axelsson E, Tedeschi A, Galjart $\mathrm{N}$, et al. Cohesin is positioned in mammalian genomes by transcription, CTCF and Wapl. Nature (2017) 544:503-7. doi: 10.1038/nature22063

157. Haarhuis JHI, van der Weide RH, Blomen VA, Yanez-Cuna JO, Amendola M, van Ruiten MS, et al. The Cohesin Release Factor WAPL Restricts Chromatin Loop Extension. Cell (2017) 169:693-707.e14. doi: 10.1016/ j.cell.2017.04.013

158. Vian L, Pekowska A, Rao SSP, Kieffer-Kwon KR, Jung S, Baranello L, et al. The Energetics and Physiological Impact of Cohesin Extrusion. Cell (2018) 173:1165-78.e20. doi: 10.1016/j.cell.2018.03.072

159. Phillips-Cremins JE, Corces VG. Chromatin insulators: linking genome organization to cellular function. Mol Cell (2013) 50:461-74. doi: 10.1016/ j.molcel.2013.04.018

160. Hanssen LLP, Kassouf MT, Oudelaar AM, Biggs D, Preece C, Downes DJ, et al. Tissue-specific CTCF-cohesin-mediated chromatin architecture delimits enhancer interactions and function in vivo. Nat Cell Biol (2017) 19:952-61. doi: 10.1038/ncb3573

161. Sekimata M, Perez-Melgosa M, Miller SA, Weinmann AS, Sabo PJ, Sandstrom R, et al. CCCTC-binding factor and the transcription factor Tbet orchestrate $\mathrm{T}$ helper 1 cell-specific structure and function at the interferon-gamma locus. Immunity (2009) 31:551-64. doi: 10.1016/ j.immuni.2009.08.021

162. Ribeiro de Almeida C, Heath H, Krpic S, Dingjan GM, van Hamburg JP, Bergen I, et al. Critical role for the transcription regulator CCCTC-binding factor in the control of Th2 cytokine expression. J Immunol (2009) 182:9991010. doi: 10.4049/jimmunol.182.2.999

163. Liu CF, Brandt GS, Hoang QQ, Naumova N, Lazarevic V, Hwang ES, et al. Crystal structure of the DNA binding domain of the transcription factor Tbet suggests simultaneous recognition of distant genome sites. Proc Natl Acad Sci USA (2016) 113:E6572-81. doi: 10.1073/pnas.1613914113

164. Li P, Mitra S, Spolski R, Oh J, Liao W, Tang Z, et al. STAT5-mediated chromatin interactions in superenhancers activate IL-2 highly inducible genes: Functional dissection of the Il2ra gene locus. Proc Natl Acad Sci USA (2017) 114:12111-9. doi: 10.1073/pnas.1714019114

165. Batista PJ, Chang HY. Long noncoding RNAs: cellular address codes in development and disease. Cell (2013) 152:1298-307. doi: 10.1016/ j.cell.2013.02.012

166. Heward JA, Lindsay MA. Long non-coding RNAs in the regulation of the immune response. Trends Immunol (2014) 35:408-19. doi: 10.1016/ j.it.2014.07.005

167. Pefanis E, Wang J, Rothschild G, Lim J, Kazadi D, Sun J, et al. RNA exosomeregulated long non-coding RNA transcription controls super-enhancer activity. Cell (2015) 161:774-89. doi: 10.1016/j.cell.2015.04.034

168. Suzuki HI, Young RA, Sharp PA. Super-Enhancer-Mediated RNA Processing Revealed by Integrative MicroRNA Network Analysis. Cell (2017) 168:1000-14.e15. doi: 10.1016/j.cell.2017.02.015

169. Anderson KM, Anderson DM, McAnally JR, Shelton JM, Bassel-Duby R, Olson EN. Transcription of the non-coding RNA upperhand controls Hand2 expression and heart development. Nature (2016) 539:433-6. doi: 10.1038/ nature20128

170. Spurlock CF3, Shaginurova G, Tossberg JT, Hester JD, Chapman N, Guo Y, et al. Profiles of Long Noncoding RNAs in Human Naive and Memory T Cells. J Immunol (2017) 199:547-58. doi: 10.4049/jimmunol.1700232

171. Steiner DF, Thomas MF, Hu JK, Yang Z, Babiarz JE, Allen CD, et al. MicroRNA-29 regulates T-box transcription factors and interferon-gamma production in helper T cells. Immunity (2011) 35:169-81. doi: 10.1016/ j.immuni.2011.07.009

172. Ma F, Xu S, Liu X, Zhang Q, Xu X, Liu M, et al. The microRNA miR-29 controls innate and adaptive immune responses to intracellular bacterial infection by targeting interferon-gamma. Nat Immunol (2011) 12:861-9. doi: 10.1038/ni.2073

173. Thai TH, Calado DP, Casola S, Ansel KM, Xiao C, Xue Y, et al. Regulation of the germinal center response by microRNA-155. Science (2007) 316:604-8. doi: 10.1126/science.1141229

174. Jiang S, Li C, Olive V, Lykken E, Feng F, Sevilla J, et al. Molecular dissection of the miR-17-92 cluster's critical dual roles in promoting Th1 responses and preventing inducible Treg differentiation. Blood (2011) 118:5487-97. doi: 10.1182/blood-2011-05-355644
175. Rodriguez A, Vigorito E, Clare S, Warren MV, Couttet P, Soond DR, et al. Requirement of bic/microRNA-155 for normal immune function. Science (2007) 316:608-11. doi: 10.1126/science.1139253

176. Banerjee A, Schambach F, DeJong CS, Hammond SM, Reiner SL. MicroRNA-155 inhibits IFN-gamma signaling in CD4+ T cells. Eur J Immunol (2010) 40:225-31. doi: 10.1002/eji.200939381

177. Simpson LJ, Patel S, Bhakta NR, Choy DF, Brightbill HD, Ren X, et al. A microRNA upregulated in asthma airway $\mathrm{T}$ cells promotes $\mathrm{TH} 2$ cytokine production. Nat Immunol (2014) 15:1162-70. doi: 10.1038/ni.3026

178. Berrien-Elliott MM, Sun Y, Neal C, Ireland A, Trissal MC, Sullivan RP, et al. MicroRNA-142 is critical for the homeostasis and function of type 1 innate lymphoid cells. Immunity (2019) 51:479-90.e6. doi: 10.1016/j.immuni. 2019.06 .016

179. Hudson WH, Prokhnevska N, Gensheimer J, Akondy R, McGuire DJ, Ahmed R, et al. Expression of novel long noncoding RNAs defines virusspecific effector and memory CD8(+) T cells. Nat Commun (2019) 10:196. doi: 10.1038/s41467-018-07956-7

180. Kotzin JJ, Iseka F, Wright J, Basavappa MG, Clark ML, Ali MA, et al. The long noncoding RNA Morrbid regulates CD8 T cells in response to viral infection. Proc Natl Acad Sci U.S.A. (2019) 116:11916-25. doi: 10.1073/ pnas. 1819457116

181. Hu G, Tang Q, Sharma S, Yu F, Escobar TM, Muljo SA, et al. Expression and regulation of intergenic long noncoding RNAs during $\mathrm{T}$ cell development and differentiation. Nat Immunol (2013) 14:1190-8. doi: 10.1038/ni.2712

182. Spurlock CF3, Tossberg JT, Guo Y, Collier SP, Crooke PS3, Aune TM. Expression and functions of long noncoding RNAs during human $\mathrm{T}$ helper cell differentiation. Nat Commun (2015) 6:6932. doi: 10.1038/ ncomms 7932

183. Petermann F, Pekowska A, Johnson CA, Jankovic D, Shih HY, Jiang K, et al. The magnitude of IFN-gamma responses is fine-tuned by DNA architecture and the non-coding transcript of Ifng-as1. Mol Cell (2019) 75:1229-42.e5. doi: 10.1016/j.molcel.2019.06.025

184. Gomez JA, Wapinski OL, Yang YW, Bureau JF, Gopinath S, Monack DM, et al. The NeST long ncRNA controls microbial susceptibility and epigenetic activation of the interferon-gamma locus. Cell (2013) 152:743-54. doi: 10.1016/j.cell.2013.01.015

185. Collier SP, Collins PL, Williams CL, Boothby MR, Aune TM. Cutting edge: influence of Tmevpgl, a long intergenic noncoding RNA, on the expression of Ifng by Th1 cells. J Immunol (2012) 189:2084-8. doi: 10.4049/ jimmunol.1200774

186. Collier SP, Henderson MA, Tossberg JT, Aune TM. Regulation of the Th1 genomic locus from Ifng through Tmevpg1 by T-bet. J Immunol (2014) 193:3959-65. doi: 10.4049/jimmunol.1401099

187. Collier SP, Henderson MA, Tossberg JT, Aune TM. Regulation of the Th1 genomic locus from Ifng through Tmevpg1 by T-bet. J Immunol (2014) 193:3959-65. doi: 10.4049/jimmunol.1401099

188. Mowel WK, McCright SJ, Kotzin JJ, Collet MA, Uyar A, Chen X, et al. Group 1 innate lymphoid cell lineage identity is determined by a cis-regulatory element marked by a long non-coding RNA. Immunity (2017) 47:435-49.e8. doi: 10.1016/j.immuni.2017.08.012

189. Liu B, Ye B, Yang L, Zhu X, Huang G, Zhu P, et al. Long noncoding RNA $\operatorname{lncKdm} 2 b$ is required for ILC3 maintenance by initiation of Zfp292 expression. Nat Immunol (2017) 18:499-508. doi: 10.1038/ni.3712

190. Liu B, Ye B, Zhu X, Yang L, Li H, Liu N, et al. An inducible circular RNA circKcnt2 inhibits ILC3 activation to facilitate colitis resolution. Nat Commun (2020) 11:4076. doi: 10.1038/s41467-020-17944-5

Conflict of Interest: The authors declare that the research was conducted in the absence of any commercial or financial relationships that could be construed as a potential conflict of interest.

Copyright (C) 2021 Fernando, Sciumè, O'Shea and Shih. This is an open-access article distributed under the terms of the Creative Commons Attribution License (CC BY). The use, distribution or reproduction in other forums is permitted, provided the original author(s) and the copyright owner(s) are credited and that the original publication in this journal is cited, in accordance with accepted academic practice. No use, distribution or reproduction is permitted which does not comply with these terms. 


\section{GLOSSARY}

Regulatory elements (REs) Non-coding sequences that control gene expression through physical interactions and recruitment of transcription factors and transcriptional apparatus. REs can be functionally classified as promoters, enhancers, silencers and insulators depending on their genomic locations and bound molecules.

Regulomes The whole set of regulatory components that control cell identity and functionality. These components include transcription factors and their co-activators/ co-repressors that modulate gene expression levels through chromatin remodeling.

Innate lymphoid cells Innate immune cells that execute effector functions (ILCs) as T lymphocytes without the expression of T cell receptors or the need of $\mathrm{T}$ cell receptor signaling for activation. ILCs are enriched at barrier surfaces and play critical roles in tissue integrity, homeostasis and the primary immune response.

Pioneer transcription TFs that bind specific DNA sequences among factors (TFs) compacted chromatin regions that are tightly wrapped by nucleosomes. Pioneer TFs then initiate stepwise chromatin remodeling to "open" the chromatin and recruit other non-pioneer TFs for gene regulation.

Lineage-determining Also called master regulators. Transcription factors transcription factors that are expressed at specific developmental stages for cell fate decisions and lineage commitment. LDTFs are often recognized as pioneer TFs.

Signal-regulated transcription factors (SRTFs) Transcription factors that are activated by external stimuli and bind to REs to convert environmental inputs to transcriptional outputs.

Poised enhancers

Enhancers that have been recognized and opened by pioneer TFs (often LDTFs) during development and can be further activated by SRTFs upon stimulation.

De novo enhancers Closed, inactive enhancer loci that can be rewired by SRTFs upon stimulation.

Phase separation A physicochemical process by which molecules segregate into a dense phase and a dilute phase. Recent studies revealed that transcription factors and co-factors can utilize the interaction of their intrinsically disordered regions to induce phase separation and form biomolecular condensates for enhancer complex assembly.

Topologically associating Megabase-sized genomic loci in proximity that form domains (TADs) an interacting chromatin hub in three-dimensional nuclear space. The boundaries of TADs often define enhancer targets and the genes that are co-regulated. 